\title{
The Development of Psychomotoric Appraisal Instrument in Fundamental Barber Practices - The Effort in Increasing the Learning Process of Barber Lecture Subject
}

\section{Lilis Jubaedah}

Vocational Education Program, Beauty and Health Department, Faculty of Engineering, Jakarta State University (UNJ)

\section{Abstract}

The purpose of this research is in order to increase an effective learning in the subject of barber through the appraisal of university student learning result to the development of appraisal instrument of barber subject which is valid, reliable, and effective. The time and place of this research should be implemented from the process of observation to the reporting which is calculated from January-October 2018, be implemented in study

Corresponding Author:

Lilis Jubaedah

lis_jb@yahoo.com

Received: 11 January 2019

Accepted: 14 February 2019

Published: 25 March 2019

Publishing services provided by Knowledge E

(c) Lilis Jubaedah. This article is distributed under the terms of the Creative Commons

Attribution License, which permits unrestricted use and redistribution provided that the original author and source are credited.

Selection and Peer-review under the responsibility of the $3 \mathrm{rd}$ ICTVET 2018 Conference Committee.

\section{G OPEN ACCESS} program of beauty and health education of Jakarta State University UNJ, H Building, 3rd Floor, 307th room, Jalan rawamangun muka, East Jakarta.

The result of this research conclude that whereas psychomotoric appraisal instrument in the practice of barber that have been developed fulfill the criteria of reliable base on the result of practice appraisal instrument test result, namely about 0.805 that points out the level of instrument reliability in good category because of $\alpha>0.7$. The appraisal instrument for the practice of barber that have been developed have been stated as effective bade on the result of appraisal instrument effectivity for practice, namely 0.4 that points out that whereas the instrument that be made have level of effectivity in the middle thing because it is in the rage pf 0.3-0.69.

Keywords: the development of practice appraisal instrument barber practice

\section{Introduction}

In ministerial regulation diknas Number 16/2007 about qualification standard of academic and competency for teacher of subject (including vocational high school teacher namely to develop the appraisal of learning result. Ideally the development is the effort of education both formal and informal be implemented consciously, have a planning, have a direction, regularly and responsibility in order to introduce, to grow, to guide, to develop the fundamental of privacy which is balance, complete, harmony, knowledgeable, have a skill as suitable to the talent, willingness and abilities, as the provision of willingness to add, to increase, to develop ourselves to the achievement 
of destiny, quality and the ability of human being which is optima; authorized privacy. that can be made the conclusion whereas the development is an effort that be done consciously, planned, directed to make or to develop and to increase the quality so that become more functional product to increase the quality as the effort for creating more better quality.

The terminology of measurement is the way of going the numbers to attribute of object, person or event that be done for appointment the difference in total thing [1]. Because of that the measurement is to compare something that be measured by the device of measurement, after that to describe the decided number base on decided regulation. This measurement is used for the process in knowing the achievement of the result of study, activity of student result appraisal be done after the lecturer/teacher implement the activity of measurement. The appraisal is one of some main tasks of teacher in learning. The teacher give the mark or grade of study result from the student or participant of education as suitable to the ability from the student through test or examination. Because of that, The function of appraisal is as the monitoring of student's activity in process of learning- teaching to reach the decided purpose.

In ministerial regulation diknas Number 16/2007 about qualification standard of academic and competency for the teacher of subject (including vocational high school teacher) be stated whereas the competency of subject lecturer is to develop the appraisal of study result. Instrument is the tool which is used to do something, the device of advice of research (is a set of test and so on) to collect the data as the material of processing. Test is an instrument or procedure which is systematic that measure the decided behavior use a set of questions [2]. In the appraisal of education such as the appraisal of ability of university student in the practice of barber, only measure the decided characteristic of student means the lecturer can measure the knowledge, attitude or the skill of university student for practice of barber that have been taught. Realization of the result of measurement is number form of data both by scale of 10 and scale of 100 .

In the subject of barber there is in curriculum of study program of makeup education in Jakarta state University is one of some subjects that in it learn about practice by description of such subject is "University student have knowledge and skill in diagnosing the skin of head and hair, analysis of form of face, history of barber, function of role and also the terminology in barber activity, forms of barber (Solid form, Layered form, Graduation form) kinds of barber's model which is suitable to development of newest model and its management". 
The subject of this practice is the application of fundamental of theory and the ability of practice fundamentally that be gotten before. This subject need the ability of high master piece. The characteristic of this practice subject be categorized in the result of learning in the form of barber result, because of that ideally this matter is suitable become the material of learning for knowing the result of study for university student which can be done by the method of observation through an instrument of appraisal which is standard or basic, in the meaning that the instrument of such appraisal for $a[$ [raising the process and the result after doing practice Based on the result of survey of the university student of makeup education that have been get the subject of barber in Jakarta State university be gotten the data through the survey and the observation in the subject of barber whereas the lecturer in the process of their learning have been use a set of study as suitable to their competency namely RPS (Rencana Pembelajara Semester/Semester learning Planning), but the lecturer do not develop yet the instrument of appraisal in the form of sheet of appraisal which is standard and basic thing, The lecturer still use the appraisal from the aspect of observation, affective and subjective. The consequence which is occurred from the appraisal of subject of barber do not illustrate completely the ability that be done when the university student is doing the practice. To observe such matter, it is important to be developed a product namely clear, standard and basic appraisal instrument in order to be able to measure the result of practice for university student in reality thing.

Because of that, it is important for this research about an activity in making an instrument of appraisal that to be used for appraisal the result of study, whereas the aspect that be appraised namely aspect of cognitive, affective and psychomotoric in the subject of barber in study program of makeup education. Orientation of this result is the development of standardized or basic appraisal instrument. This research is the research of development that create a set of appraisal instrument can be used by the lecturer as the reference in evaluating the process and the result of practice for the subject of barber

Base on the description above, there is the needs for developing the instrument of appraisal because the instrument that be used is not suitable yet, where the instrument of appraisal refer to three domains of study result namely aspect of cognitive, affective and psychomotoric which is standardized and basic that be used for the practicing of university student. Because of that, It is important to do the research and development about the development of appraisal instrument for practice in the subject of barber. Be hoped, this research can assist the lecturer in doing the appraisal of psychomotoric in the practice of university student 


\section{Methods and Equipment}

\subsection{Methods}

In this research, the place that be used is the campus of Jakarta State University, $\mathrm{H}$ Building, $3^{\text {rd }}$ floor, $307^{\text {th }}$ room, laboratory of hair beauty management. JI Rawamangun Muka, East Jakarta. Time of research be done on January - October 2018, where is calculated for this research be done from observation, the making of proposal to report of research.

The purpose of this research is in order to increase the process of effective learning in the subject of barber. And to give the revision and the same thing of it through the result of learning of university student by developing of appraisal instrument in the subject of hair barber which is valid, reliable and effective.

Method of appraisal that be used in this research is Research and Development (R\&D), that be adopted from the model of Borg and Gall 1989. it is the model of development whereas their research be used for designing the new product and procedure that be tested in the field, be evaluated, and be perfected so that fulfill the decided criteria. The meant product in this research is the development of appraisal instrument that be done through some steps that be done in design of its research. Design of research involve some steps that be illustrated in following Figure 1:

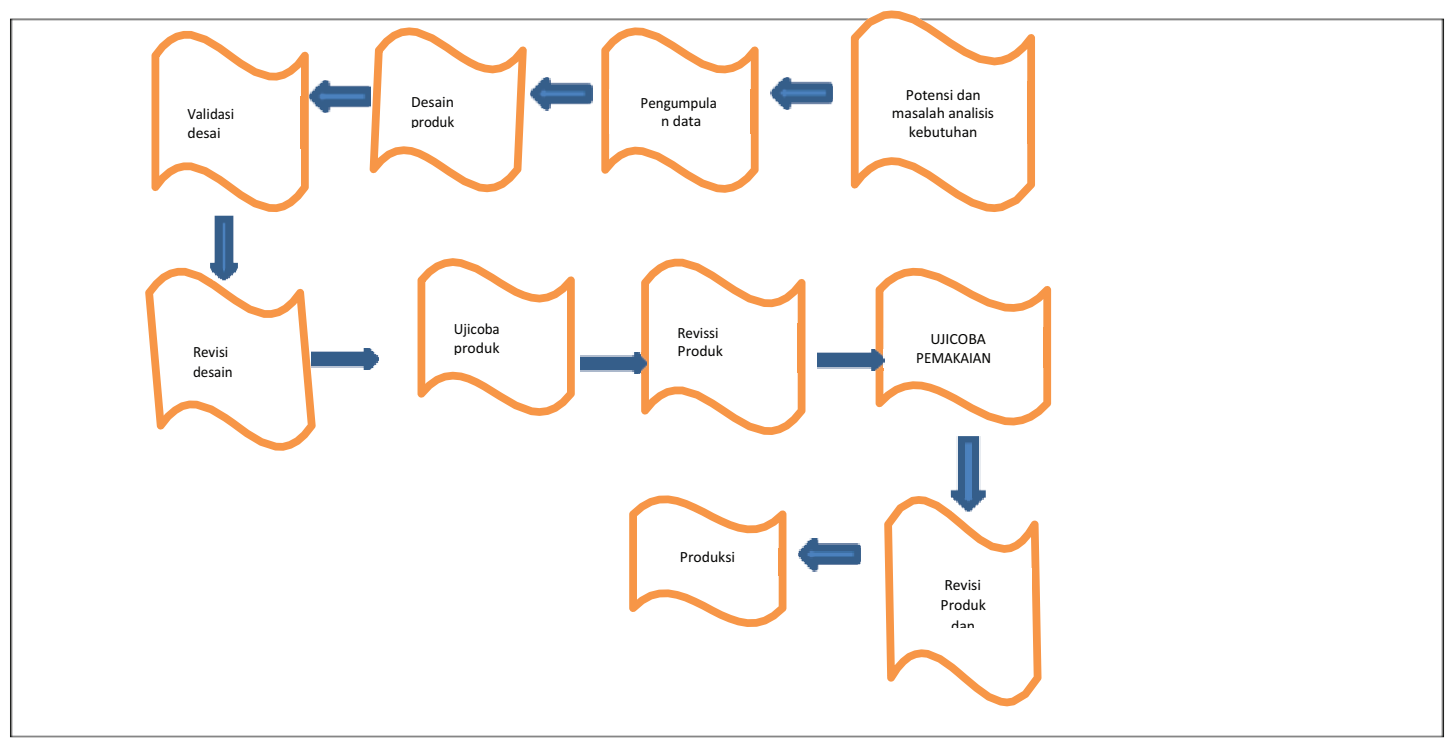

Figure 1: The steps of research and the development [3] 


\section{Results}

In Research and Development (Research and Development) abbreviated as R \& D has the aim to produce a haircut practice assessment instrument, which is carried out in the Hair Beauty Laboratory, S1 UNJ cosmetology education study program, $\mathrm{H}$ floor3 building, JI Rawamangun depan, East Jakarta. During January-October 2018, where this process runs from the start of the observations.

\subsection{The result of potency and problem (Needs analysis)}

At the stage of getting the results of the potential that exist in the Education Study Program S.1. Cosmetology, at, barber courses are very important, have a career potential, and always have competency tests for students. Problem or needs analysis is done by observing in the field to collect data about the problems that exist in the field. Based on the results of observations and interviews in the field, during the implementation of learning courses, cut the hairs with the burden of SKS 2 on the education study program for strata one makeup. The curriculum in the strata one cosmetology study program is competency-based because the strata one is education that produces educators such as makeup teachers.

Lecturer lectures on haircutting in the study program of strata one makeup, in the evaluation of learning using assessment tools but still not perfect and does not measure specifically the trimming techniques made. The assessment instruments used for barbering are mainly solid and graduation techniques. In assessing the practice of barbering, the lecturer assesses the end result of the practice based on lecturer observation, so the results are subjective, and the assessment between lecturers is different. If the lecturer only assesses the final results of the practice, the lecturer cannot judge from the preparation of practical work to trimming the hair, but only looking at it but not being assessed. This causes the lack of validity of the lecturers' assessment of the practice end results of student haircut.

\subsection{Data collecting}

Problem analysis or research needs are done by field observation to collect data about the problems that exist in the field. Based on the results of observations and interviews in the field, during the implementation of the haircutting course which had a weight of 2 credits. Within 1 (one) practice score is 100 minutes of learning. If 2 (two) credits are 
equivalent to 200 minutes of learning or 3 hours 20 minutes of learning. Conducted in 16 meetings. In one semester.

\subsection{Design of product that be developed}

This stage is by compiling instrument lattice and instrument items The steps in designing and developing a practice assessment sheet are as follows:

\section{To arrange the instrument grid}

Practical assessment instruments designed in the form of an observation sheet assessment instrument to assess student attitudes and psychomotor in practice. Before making a practical assessment instrument, first prepare the instrument lattice. In determining the instrument lattice, it is necessary to pay attention to what matters are in practice assessment, so that all aspects can be assessed according to their competence.

\section{To arrange the instrument items}

Instrument items are prepared according to the instrument's specifications and specifications that have been determined to be standard practice assessment sheets that are in line with the expected competencies.

\subsection{The result of expert validation}

Based on the table above, the score of the material validator is 76 , the evaluation expert validator is 29 , and the subject lecturer is 23 and the skin beauty expert is 24 . The total value obtained is 76 which indicates this instrument is in the criteria "very good

After determining the criteria of expert validation results, the next step is to calculate the reliability between validators using SPSS Version 22 . The results obtained are as follows:

value Alpha r 0.805 category very good because of the value alpha $>0.8$. 


\subsection{Revision result of beginning product}

The beginning product revision phase is an activity to revise and improve products that have been validated by experts/validators, based on input and suggestions from experts.

After getting input and advice from expert validators, then the initial instrument revision is made to be used in the next stage

\subsection{The result of limited trial and error}

The trial was carried out by giving two types of tests namely pretest and posttest. At pretest did not use assessment instruments and at posttest had used assessment instruments.

Because PV count $<\alpha 0.05$ or $0.00<0.05$, Ho is rejected There is a significant difference between the pretest and Posttest or there are significant differences between old instruments and new instruments at the initial validation stage.

\subsection{The result of product revision}

Based on the results of limited trials will get an assessment. The results of the assessment are used to make changes as an improvement of the assessment instrument sheet to obtain an assessment instrument that has a level of validity and effectiveness

\subsection{The result of making a wide for trial and error}

The results of the expanded trials were then analyzed and revised to obtain practical assessment instruments. The trial of the practical assessment instrument was carried out with an experimental design, namely using the true experimental design method with pretest-posttest control group design data from expanded trials not much different from the limited trial data, namely the difference in values between pretest and posttest on cognitive aspects was only 0,3 , and differences in attitude and psychomotor aspects of 0.4. In the cognitive aspect, the student's score has decreased, while the student's attitude and psychomotor aspects have increased due to the increasing frequency of students practicing, the more skilled students are in doing barber practice 


\subsection{Analysis of instrument product validation}

The validity of the practice assessment instrument is calculated based on the Product Moment Correlation formula resulting in a value of 0.825 which indicates valid because the r-Calculate value is greater than the r-table value.

\subsection{Analysis of job preparation aspect validation}

\subsubsection{Analysis of instrument product validity}

A valid instrument is if the results of the research are valid and there are similarities between the data collected and the actual data that occurs in the object under study [4]. A valid instrument means that the measuring instrument used to obtain data (measuring) is valid.

To calculate the validity percentage each validator is used the following formula:

$$
p=\frac{F}{N} \times 100 \%
$$

Based on the calculation of the calculation of item validity in the assessment aspects of the work above and referring to Sugiyono's opinion, it can be concluded that of the five items can be used as an assessment instrument because it meets the valid and very valid criteria.

\subsubsection{Validity analysis for process aspect}

It can be concluded that all of these items can be used as an assessment instrument because they meet the criteria for being very valid and valid

\subsection{Analysis of validity for evaluation aspect of the job result}

The results of the analysis of each item on the aspects of work are as follows:

Based on the calculation of item validity calculations on the aspects of the work above and referring to Sugiyono's opinion, it can be concluded that from the five items can be used as an assessment instrument because it meets very valid criteria

\subsection{Time aspect}

The results of each item analysis on the time aspect are as follows: 
Based on the calculation of item validity calculations on the above aspects of time, it can be concluded that of the five items can be used as an assessment instrument because it meets the very valid criteria

\subsection{The packaging aspect}

Based on the calculation of item validity calculations on the above aspects of time, it can be concluded that from the five items can be used as an assessment instrument because it meets the criteria and is very valid.

\subsection{Reliability test of practice appraisal instrument}

Reliability according to Sugiyono (2015: 182) is the degree of consistency/constancy of an instrument. The instrument is declared reliable, if the instrument is used to measure the same object/subject by the same or different people at different times, it will produce relatively the same data.

Reliability tests of instrument items were calculated using the kappa coefficient analysis from Cohen. Inter-rater reliability is used to assess the consistency of two Rater in assessing individual performance through a checklist that produces nominal data

Instrument reliability analysis was calculated using the kappa coefficient formula, which compares the two rater (two lecturers) assessments. The results of the instrument reliability obtained is equal to 0.739 which shows the level of reliability of the instrument into a good category because of the alpha value $>0.7$.

\subsection{Instrument effectivity}

\subsubsection{Analysis of instrument product effectivity}

A valid instrument is if the results of the research are valid and there are similarities between the data collected and the actual data that occurs in the object under study [3].A valid instrument means that the measuring instrument used to obtain data (measuring) is valid.

The effectiveness test in this study was used to determine whether or not there was a significant increase after the learning process after using an assessment instrument 
on the practice of normal facial skin care. Effectiveness test was analyzed by using normalized gain test to determine the increase in pretest and posttest values.

TABLE 1: The result of Normalized Gain Test.

\begin{tabular}{|c|c|c|}
\hline \multicolumn{2}{|c|}{ Average } & \multirow[t]{2}{*}{ N-Gain } \\
\hline pretest & posttest & \\
\hline 73 & 81 & 0.4 \\
\hline
\end{tabular}

Based on the results of the normalized gain test above, a value of 0.4 is obtained, which indicates that the instrument made has a moderate effectiveness because it is in the range of 0.3-0.69.

\section{Discussion}

Based on the results of the analysis of the effectiveness of the instrument, practical assessment is only obtained at a moderate level of the results of interviews with haircutter lecturers manually, it can be concluded that: 1) there is an assessment instrument developed to assess the results of student practice, students do not know whether the lecturer assesses using the instrument sheet or not; 2) before giving an assessment, the lecturer already has an overview of the results of student practice even though globally, it is not perfectly documented; 3 ) lecturers in assessing already have an assessment of the results of good and bad student practice results, except lecturers who do not have experience in assessing barber, then assessment instruments are needed as an assessment guide; 4) without using an assessment instrument, the lecturer has assessed globally that the results are not much different from the lecturer who assesses using an assessment instrument but in terms of quality, assessment of practice using an assessment instrument, the measured assessment results can be seen in detail aspects that are assessed and known clear weighting score.

\section{References}

[1] Purwanto. 2011. Evaluasi Hasil Belajar. Yogyakarta: Pustaka Pelajar.

[2] Herman \& Yustiana. 2014. Penilaian Belajar Siswa di Sekolah. Jakarta: PT Kanisius

[3] Sugiyono. 2015. Metode Penelitian \& Pengembangan Research \& Development. Bandung: Alfabeta.

[4] Sugiyono. 2010. Metode Penelitian Administrasi. Cetakan ke 18 Bandung: Alfabeta.

[5] Aries, E. F. 2011. Penilaian dan Evaluasi. Yogyakarta: Aditya Media Publishing. 